\title{
16
}

\section{Heading towards the Restoration and Transmission of Ainu Culture}

\author{
Nobuko Tsuda (translated by Hiroshi Maruyama)
}

When attaining puberty, I tried to hide that I was an Ainu by removing the hair on my hands and feet - 'hairiness' is a feature said to be representative of the Ainu. I often heard negative ideas about the Ainu: the Ainu language has no written form; the Ainu have no sense of propriety; the Ainu are inferior to the ethnic Japanese. I am of mixed Japanese and Ainu background, but I had been troubled by my blood relationship with the Ainu for a long time. One day, I realised that the Ainu have inhabited this land, which is called Hokkaidō at present, since time immemorial, and that our ancestors handed down their wisdom for living in harsh winters, for example, how to make their houses, instruments of everyday life and clothing. This realisation connected me later with my job at the Hokkaidō Center for Ainu People. The Ainu Association of Hokkaidō is entrusted with the management of the centre by the Hokkaidō Government, and provides information on the history and culture of Ainu people for visitors. Before describing how I have revitalised Ainu embroidery (see Figure 11), I want to record some memories of my family.

My paternal grandfather, named Ekashimatkk, was born in 1876 and died in 1958. When I was four or five years old, he talked to me about how to catch and eat sirkap (swordfish). Also, he talked to me about rakko (sea otter) hunting in the sea. While listening to his stories while he sat cross-legged, I felt like I was riding waves whenever he shook 
his body. When I was seven years old, my sister died at the age of three. My grandmother cried in front of the memorial tablet while leaning her body many times in many directions. Her tearful voice had a sad tune and that lasted a long time. I realised at a later date that it was an Ainu manner to mourn the deceased. In my childhood, I was curious to see tattoos around the mouth and on the arms of my grandmother.

My father was born in 1923 and died in 1988. My parents had only Japanese names, while my grandparents had Ainu names. My father often accompanied his father to the neighbouring mountains to hunt weasels, foxes and raccoon dogs in winter. At the same time, he often cast a net to catch fish in the neighbouring river. I later saw him making shapely Ainu folk utensils, including inaw (ritual wooden shaving stick), ikupasuy (a prayer stick) and heperay (a ritual arrow). My memory of Ainu knitted goods was traced back to my childhood. I had the experience of seeing my aunt, who lived in my neighbourhood, knitting cotton into an emusat (a cord from which a sword is hung over the shoulder) like a magician.

When I was older than 40 years, I felt impelled to learn about Ainu culture. I appealed to museums and persons who were working on the transmission of Ainu culture to be taught. Those persons included Urakawa Tare in Urakawa, Sirasawa Nabe in Chitose, Sasamura Toyo in Chitose, Sugimura Kyoko in Asahikawa, Nakamoto Mutsu in Chitose and Toyama Saki in Anecha. They revered almost all natural resources for food and instruments of everyday life, considering them as gods, and had knowledge and techniques that enabled them to live in harmony with nature. They taught me not only craftsmanship, but also Ainu ways of thinking and Ainu perceptions of spirituality. I learned from them a principal rule that handicrafts tell us the state of culture when they are produced. In addition, Ainu clothing and miscellaneous goods, which were made by Ainu women with pious prayers, are considered to have strengthened Ainu people's sense of belonging and to have connected Ainu people with each other.

In 1994, at the age of nearly 50 years and having finished raising my children, I started my career as curator of the Hokkaidō Center for Ainu People. I provided people who intend to learn about Ainu culture with a program of craftsmanship. In the course for making pon saranip (a small knitted basket), participants made a sack from string. In the course for knitting tar (a rope used to carry loads on the shoulders), participants learnt the basic technique of Ainu embroidery such as how to knit, 
twist and plait thread. Participants knitted a rush mat from cattails in the course for making a chitarpe (a rush mat), and they made a small sack or a covering for the back of the hand and wrist in the guide to Ainu embroidery course. These courses were taught on the seventh floor of a building. Unfortunately, the participants could not learn about the materials for these courses, where they were collected, and how they were processed. In order to hand Ainu traditions of craftsmanship down on to the next generation, we need to intentionally learn and become proficient at Ainu perceptions of spirituality and techniques through experience.

One day, I saw a tar or packing rope made by Ainu among the excavated items in the Bibi 8 remains from 270 or 300 years ago, in Chitose. My research into tar demonstrates that it is made of herringbone patterns and that the technique traditionally used to interweave the tar is not seen today. Also, I found a sack for flints in the Museum of the Department of Agriculture of Hokkaidō University. It was made from cattails and had more complex herringbone patterns than the tar. No Ainu women knew how to make this pattern, so I restored the complex herringbone patterns on my own. I was successful in knitting emusat in addition to tar by analysing the emusat that had been collected by the above-mentioned museum. Further, I was able to restore the technique to create a pair of shoes from salmon skin by referring to a video archive that shows Kato Katsuyo making shoes from salmon skin in Teshikaga in 1988. Based on these experiences, I would like to say that it is important to digitally record cultural activities for the transmission of traditional techniques from generation to generation.
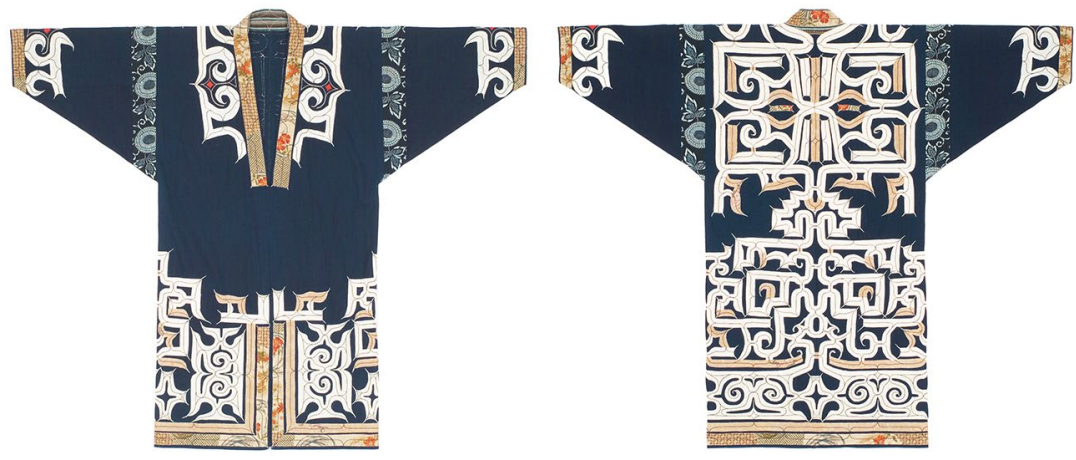

Figure 11. This ruunpe (a traditional Ainu dress) was modelled on a work exhibited in the Hokkaidō Museum. Artist Nobuko Tsuda.

Source. Photographed by the artist's husband, Hiroaki Tsuda, summer 2006. 
In Japan, tens of thousands of Ainu items are kept in museums. However, they tend to lack fundamental information (provenance), including when, where and by whom those items were made or used. In contrast, Ainu items in foreign countries, especially in the West, have such information recorded and this helps researchers understand the characteristics of Ainu culture in specific areas and periods. I hope the progress of research on Ainu items made in the West will encourage us to organise information on Ainu items in Japan. In May 1999, I had a chance to see Ainu items held by the University of Pennsylvania Museum of Archaeology and Anthropology in Philadelphia, and by the Smithsonian in Washington DC. At the University of Pennsylvania Museum, I saw Ainu items, including embroidery, from Usu and Shiraoi in Hokkaidō, and exchanged opinions about threads, ways of knitting and Ainu patterns with the curator. I realised again how important such exchange is for the full-fledged revitalisation of Ainu culture. In the Smithsonian, the Ainu items, as well as items from Okinawa, were classified by area and period, and preserved in a repository in which climate conditions were controlled. Additionally, each of the Ainu items, which were labelled, could be accessed through the internet.

In December 1998, I called Ainu women, who were involved in the transmission of Ainu culture, to organise the Association of Ainu Women for the Transmission of Ainu Culture, commonly known as Karip. The association aims to improve our skill through involvement in the restoration of traditional works, to learn how to make Ainu embroidery from records or direct interviews with elderly memory keepers, and to strengthen connections between the members across the area. The first project of the association was to knit the rush mat, saranip and emusat, using traditional techniques, and to hold a workshop on upopo and mukkuri for the 1999 special exhibition of the Ainu in the Smithsonian. On display were a variety of Ainu folk utensils made from the Jomon Period (13,000-300 BC) to the Meiji Era (AD 1868-1912), a chise or Ainu traditional house built by Nomoto Masahiro, carvings by Sunazawa Bikki, and so on. Unfortunately, there were not many modern Ainu works using traditional techniques on display. Overall, I was proud of the Ainu cultural items from the northern part of Japan, which attracted many visitors to the Smithsonian. 
Many researchers came to the Hokkaidō Center for Ainu People. When I was nearly 60 years old, a Japanese anthropologist gave me the opportunity of taking a master's degree at his university. Afterwards, another Japanese anthropologist encouraged me to become the first female Ainu $\mathrm{PhD}$ holder. In September 2014, I finally got my $\mathrm{PhD}$ at the age of 69, from the Graduate University for Advanced Studies in Hayama, Japan. My doctoral dissertation focuses on Ainu clothing. There were earlier studies on Ainu clothing before I wrote my dissertation (Tsuda 2014). However, those were carried out by male researchers, and were confined to the areal classification of Ainu clothing. Based on close examination of Ainu clothing collected by museums inside and outside of Japan, as well as my practical knowledge of knitting Ainu clothing I made the following findings. First, in the eighteenth century, cotton, which came to Hokkaidō from China, replaced animal skins and bark as the material from which Ainu clothing was made. Cotton was easy to process and knit, and inspired Ainu women to make a big difference to the culture of Ainu clothing. Second, earlier studies mostly showed that Ainu patterns came from China, but I concluded that Ainu patterns represent the bonds of a sacred place to avert evil, while those in China are borrowed from trees and birds. I will continue doing research on Ainu clothing and hand down information on how to view Ainu collections in museums to younger generations of the Ainu.

\section{Reference}

Tsuda, Nobuko, 2014. 'Ainu i bunka no kenkyu' [A study of Ainu clothing culture], PhD dissertation. Hayama: Graduate University for Advanced Studies. 
This text is taken from Indigenous Efflorescence: Beyond Revitalisation in Sapmi and Ainu Mosir, edited by Gerald Roche, Hiroshi Maruyama and Åsa Virdi Kroik, published 2018 by ANU Press, The Australian National University, Canberra, Australia.

doi.org/10.22459/IE.2018.16 